\title{
Mass Murder by Deliberate Indifference
}

James Bauhaus

$\mathrm{O}_{\mathrm{p}}^{\mathrm{n}}$ February 15, 2012, a prison in Honduras burned down. Over 350

people died, all of them captives who had been deliberately left to burn to death by their guards (Castillo and Sandoval, 2012). This is an old, common process that never gets fixed. Hated captives are collected and stuffed into tiny cages. Every prison ever built is slowly stuffed with more and more pariahs. A prison might be designed to be humane at first, but every time the police go lock-up crazy, while the politicians spend all the money on pet projects as prison upkeep is neglected. The police, running on autopilot, keep stuffing. When they have their cages filled to double capacity or more, the inevitable happens. As always, the captives, pushed to the breaking point, go mad.

In the case of the Honduran prison, two scenarios are being offered for public consumption. The first version is that maybe the fire was electrical. The second, more sensational version is that perhaps a captive set his sleeping pad on fire and it somehow blazed through the entire prison before anyone noticed or could get a bucket of water (Castillo and Sandoval, 2012).

In the USA, we like to pretend that we do not torture and harass our captives like they do in developing countries. This makes us feel superior, even though it has no basis in fact. We actually have had three of the worst five prison riots in the world, primarily because our police and politicians cage more people than any other nation (5 World's Biggest Prison Riots, 2013). Even China, with more than four times the US population cages far fewer people than the United States, the supposed "land of the free" (Tsai and Scommegna, 2012). We just cover our tracks better, having a police-media alliance that agrees, covertly, to report mostly happy, positive news while ignoring or underreporting news of their own corruption, incompetence, and negligence.

How do they get away with this? First, they make their stacks of cages very secret places, restricting access to cameras or voice recorders from the outside world. No one must see or hear what transpires in these hellholes and torture traps. They choke off communications too. For instance, they make phone calls prohibitively expensive for many prisoners and their loved ones (see Jackson, 2007). They also choke off communications by making it embarrassing and humiliating to call anyone. At this prison, every two minutes an annoying digital voice loudly interrupts to unnecessarily declare, "Caller is a convicted felon in prison. Beware". This is unnecessary 
because it harangues loved ones or friends with an expanded version of this speech at the beginning of every call. Moreover, captives are permitted to call only four classes of people: relatives, friends, lawyers and clergy. If the phone-monitoring software hears a click, it assumes a call was forwarded or a caller was added and abruptly terminates the call. Each call is also recorded and often monitored by staff, even if the calls are merely piped into a bullpen of secretaries or other prison or jail employees. There is no evidence that the collected calls are ever erased. Captives who use these phone services feed the sharks that cage them and drain life's blood from them and their loved ones and friends.

Prison staff pull many of the same stunts to choke off mail or prevent it from being written. They require hand-written communication in everything except legal material and have been very successful in preventing access to typewriters. Forget word processors. They block access to carbon paper, both to eliminate mail and to boost the obscene profits from their copiers. Most of the younger victims of this system are so poorly educated they do not even know that carbon paper exists.

A more subtle and insidious way that prisons prevent news of these antics from reaching public knowledge is through simple retaliation and extra punishment for being caught trying to educate people. They keep most captives too terrified to say anything. Rather than have years added to their sentences, victims of mass punishment and other illegal harassments shut up and bear the atrocities. Captives have developed a culture of hiding in the crowd and hoping that their torturers will mistakenly pass them by.

The braver ones, who are few, will almost never try to obtain humane treatment for everyone but rather will often try to sell out everyone else to obtain special treatment for themselves alone. At its worst, this sell-out philosophy creates exactly what the tormentors need most to abuse their victims: a culture of secret snitches and opportunists eager to assist in nefarious projects such as baiting operations, evidence planting, false witness, and other graft or corruption. A common scenario is planting dope for guards to "discover" and earn bonuses or prisoner property theft rings, where pet prisoners and guards conspire to send enemies or troublemakers to disciplinary units just to steal their TVs, stereos, and other valuable appliances.

Alongside these sell-outs are the instigator types. They have not the courage or wherewithal to stand up themselves to demand humane or fair treatment, but they will try to inflame others, more ignorant and trusting, to 
do so in their stead. They are usually older and full of stories of how they were heroes once, but now have paid their dues and pass the torch to others.

One such prisoner was Tommy Holcomb, who almost got us all killed because he wanted to burn down the cage because the trustees stole the sugar for the coffee. As soon as he lit the match, the jailer slammed the door, and fifteen people nearly died of smoke inhalation.

Coffee sans sugar does not sound like a very good reason to set your cage on fire with you in it but, coupled with tiny minds in large, muscular bodies and a history of harassment, a free person may begin to see that not much reason can penetrate the emotion of victims poked from all sides with sharp sticks. Also, there is the belief that jailers will not simply watch you burn to death. Any non-jailer would unlock the cage, but Tommy Holcomb has third degree burns over most of his body that testify that the jailers are trained to be very different from normal people. They will not risk their jobs to save one captive's life from death by immolation. They will ignore the screams of pain and instead try to find their boss to ask what to do. If he is so timid of his employment risks that he decides to wait until he can find and consult with his boss, 350 or more people burning to death is a small price to pay for making certain that one retains his fat government job. After all, no one was ever fired for leaving prisoners in jail.

The same ethos applies to the Honduran situation. No one will be fired, no matter what the cause of the fire. Whether electrical in nature or caused by an idiot setting his sleeping pad on fire, all blame in such settings accrues to the victims. It is simply impossible for police overstuffing and political greed to cause prisoners to go stir crazy or one to go mad and murder all the others with his madness. No, in the police world, even prisoners driven mad are responsible for their madness. News accounts will confirm this fact.

\section{REFERENCES}

Castillo, Mariano and Elvin Sandoval (2012) "More than 300 killed in Honduras prison fire" - February 16. Retrieved from < http:/www.cnn.com/2012/02/15/world/ americas/honduras-fire-deaths $>$.

Jackson, Steven J. (2007) "Mapping the Prison Telephone Industry", in Tara Herivel and Paul Wright (eds.), Prison Profiteers: Who Makes Money from Mass Incarceration, New York: The New Press, pp. 235-249.

Tsai, Tyjen and Paola Scommegna (2012) "U.S. Has World's Highest Incarceration Rate" - August. Retrieved from <http://www.prb.org/Articles/2012/us-incarceration. $\operatorname{aspx}>$. 
5 World's Biggest Prison Riots (2013). Retrieved from $<$ http://binscorner.com/pages/5/5worlds-biggest-prison-riots.html>.

\section{ABOUT THE AUTHOR}

James Bauhaus is incarcerated in Oklahoma and writes prolifically on sociological issues, science, law, injustice, and investing. He can be contacted at:

James Bauhaus \#88367 6A207

8607 SE Flower Mound Road

Lawton, Oklahoma 73501-9765

USA 